Jurnal Pendidikan dan Pembelajaran Kimia, Vol. 8, No. 2, Tahun 2019.

Program Studi Kimia. FKIP. Universitas Lampung

https://jurnal.fkip.unila.ac.id/

\title{
Pengaruh Isu Sosiosaintifik dalam Meningkatkan Model Mental Siswa pada Materi Larutan Elektrolit dan Non-Elektrolit
}

\author{
Fitri Alfionita*, Sunyono, Ratu Betta Rudibyani \\ FKIP Universitas Lampung, Jl. Prof. Dr. Soemantri Brojonegoro No.1 \\ *e-mail: Fitrialfionitaa@gmail.com, Telp: +6281532937943
}

Received:July 22, 2019

Accepted:July 24, 2019

Online Published:July 26, 2019

\begin{abstract}
The Effect of Socioscientific Issues to Improve Mental Models of Student Ability on Electrolyte and Nonelectrolyte Solutions Topic. This research was aimed to describe the effect of sosioscientific issues to improve mental models of student ability on electrolyte and nonelectrolyte solutions topic. This research method used quasi experiment with pretest posttest control group design. The population of this research were all students of X IPA. The sample was obtained by cluster random sampling technique and it was obtained sample was students of XIPA 3 as experiment class and X IPA 6 as control class. The effect of socioscientific issues was analyzed by the differences of two average test and effect size test to mental models of student ability compared with control class. The result showed that using socioscientific issues on learning had large effect to improve mental models of student ability. Based on hypothesis testing, it can be concluded that learning using Socioscientific Issues has a large effect to improve mental models of student ability.
\end{abstract}

Keywords: mental models, socioscientific issues learning, electrolyte and nonelectrolyte solutions

\begin{abstract}
Abstrak: Pengaruh Isu Sosiosaintifik dalam Meningkatkan Model Mental Siswa pada Materi Larutan Elektrolit dan Non-Elektrolit. Penelitian ini bertujuan untuk mendeskripsikan pengaruh pembelajaran isu sosiosaintifik dalam meningkatkan kemampuan model mental siswa pada materi larutan elektrolit dan non-elektrolit. Metode penelitian ini yaitu kuasi eksperimen dengan pretest-postest control group design. Populasi yang digunakan adalah seluruh siswa kelas X IPA. Pengambilan sampel dilakukan dengan cara cluster random sampling sehingga diperoleh kelas X IPA 3 sebagai kelas eksperimen dan X IPA 6 sebagai kelas kontrol. Pengaruh pembelajaran isu sosiosaintifik dianalisis menggunakan uji perbedaan dua rata-rata $n$-Gaindan uji effect size terhadap kemampuan model mental siswa dibandingkan dengan kelas kontrol. Hasil penelitian menunjukkan bahwa pembelajaran berbasis isu sosiosaintfik memiliki pengaruh yang besar dalam meningkatkan kemampuan model mental siswa. Berdasarkan pengujian hipotesis, dapat disimpulkan bahwa pembelajaran menggunakan isu sosiosaintifik memiliki pengaruh yang besar dalam meningkatkan model mental siswa.
\end{abstract}

Kata kunci: model mental, pembelajaran isu sosiosaintifik,larutan elektrolit dan nonelektrolit 


\section{PENDAHULUAN}

Kimia merupakan salah satu mata pelajaran dalam rumpun sains yang sangat erat kaitannya dengan kehidupan sehari-hari. Sains lahir dari pengamatan terhadap suatu fenomena yang dikaji secara terus menerus dan sistematis sehingga diperoleh suatu konsep ilmu.Ilmu kimia diperoleh dan dikembangkan berdasarkan percobaan namun pada perkembangan selanjutnya kimia juga diperoleh dan dikembangkan berdasarkan teori.

Berpikir dalam konteks ini adalah pola berpikir tingkat tinggi. Model mental merupakan salah satu jenis kemampuan berpikir tingkat tinggi. Menurut Sange (Sunyono, 2013) menyatakan bahwa proses berpikir seseorang memerlukan bangunan model mental yang baik. Seseorang yang mengalami kesulitan dalam mengembangkan kemampuan berpikir maka akan mengakibatkan seseorang tersebut tidak mampu melakukan pemecahan masalah dengan baik.

Model mental siswa dibangun dari pengalaman mereka, menginterpretasikan dan menjelaskan apa yang mereka lihat, merefleksikan pemahaman mereka pada level submikroskopik suatu materi dalam kimia (Junaina, 2013). Selanjutnya, Devetak menemukan bahwa siswa yang tidak dibelajarkan representasi eksternalnya, maka akan menemukan kesulitan untuk menginterpretasikan molekul dalam bentuk struktur submikroskopiknya (Sunyono, 2015a). Model mental biasanya berkembang sesuai dengan kebutuhannya dalam membuat prediksi dan menyelesaikan permasalahan dalam belajar kimia (Halim, 2013). Menurut Borges \&
Gilbert, Greca \& Moreire setiap orang menggunakan model-model mental ini untuk melakukan upaya memecahkan suatu masalah melalui proses menalar, menjelaskan, memprediksikan fenomena, atau menghasilkan model yang diekspresikan dalam berbagai bentuk (seperti diagram, gambar, grafik, simulasi atau pemodelan, aljabar, bahkan juga, deskripsi verbal dengan kata-kata atau bentuk tulisan cetak, dan lain-lain), kemudian dapat dikomunikasikan pada orang lain (Sunyono,2013).

Berdasarkan karakteristik ilmu kimia, untuk mempelajari dan memahaminya tidak cukup hanya dengan pencapaian teori saja akan tetapi siswa harus mempunyai kemampuan menghubungkan tiga level representasi kimia. Johnstone (2006) membagi representasi fenomena kimia menjadi tiga level yaitu level makroskopik, level submikroskopik, dan level simbolik. Hal ini dikarenakan pemahaman seseorang terhadap ilmu kimia ditentukan oleh kemampuannya mentransfer dan menghubungkan antara fenomena makroskopik, submikroskopik, dan simbolik (Sunyono, 2013).

Pemahaman terhadap konsep kimia sangat bergantung pada representasional siswa dan berpengaruh pada perkembangan model mental (Sunyono, 2015a). Beberapa hasil penelitian (Coll, 2008; Davidowitz, 2010) memberikan informasi bahwa siswa selalu mengalami kesulitan dalam memberikan eksplantasi tentang representasi submikro berdasarkan representasi makroskopis dan simbolis. Terkait hal ini siswa cenderung lebih banyak menggunakan transformasi level 
makroskopis ke simbolis, namun tidak mampu dalam mentransformasikan dari level makroskopis dan simbolis ke level submikroskopis (Sunyono, 2013). Hasil penelitian tersebut telah menunjukkan bahwa banyak siswa memiliki model mental yang sangat sederhana tentang fenomena kimia.

Kompetensi dasar kimia kelas $\mathrm{X}$ 3.8, merupakan salah satu kompetensi dasar kimia yang melibatkan tiga level representasi fenomena kimia. Untuk membangun pemahaman konseptual siswa dalam materi tersebut membutuhkan kemampuan untuk mempresentasikan, menerjemahkan dan menyesuaikan strategi dan kondisi pembelajaran dalam bentuk representasi makroskopik, submikroskopik, dan simbolik secara simultan (Laliyo, 2011). Pada materi ini, siswa diajak untuk mengamati gambar yang meliputi tiga level representasi fenomena kimia, mencoba (melakukan percobaan daya hantar listrik), dan menalar dengan menjawab pertanyaan. Dengan demikian, diharapkan model mental siswa akan terbentuk.

Kemampuan memecahkan masalah dan membuat keputusan dalam pembelajaran sains dapat dilakukan dengan memberikan permasalahan terkait dengan sains yang ada di sekitar kita. Salah satunya yaitu pembelajaran menggunakan isu sosiosaintifik. Isu sosiosaintifik adalah isu-isu yang menggambarkan masalah sosial masyarakat yang berhubungan dengan suatu konteks konseptual, prosedural, atau teknologi terhadap sains (Sadler, 2002). Manfaat pembelajaran menggunakan isu sosiosaintifik diantaranya mampu menumbuhkan kemampuan untuk menerapkan pengetahuan konsep dan proses ilmiah, membentuk kesadaran sosial dengan adanya diskusi dan saling berargumen, mengembangkan moral dalam pengambilan keputusan mengenai isu yang terjadi, dan menumbuhkan keterampilan berpikir kritis (Zeidler, 2005).

Berdasarkan hasil penelitian Mazfufah (2017) menyimpulkan bahwa penggunaan pembelajaran yang berbasis isu sosiosaintifik memiliki pengaruh yang signifikan terhadap kemampuan penalaran ilmiah siswa dan juga membuat siswa aktif terlibat dalam proses pembelajaran. Penggunaan isu sosiosaintifik dalam proses pembelajaran merupakan hal yang penting agar dapat menghasilkan masyarakat yang bertanggung jawab, mampu menerapkan pengetahuan ilmiahnya, serta memiliki kemampuan untuk berpikir. Berdasarkan uraian diatas, maka dilakukan penelitian dengan judul "Pengaruh Pembelajaran Berbasis Isu Sosiosaintifik dalam Meningkatkan Kemampuan Model Mental Siswa pada Materi Larutan Elektrolit Dan Non-elektrolit”.

\section{METODE PENELITIAN}

Metode penelitian yang digunakan dalam penelitian ini adalah kuasi eksperimen dengan Pretest Posttest Control Group Design (Fraenkel, 2012). Pada desain penelitian ini melibatka nperbedaan pretes maupun postes pada kelas yang diteliti. Penelitian ini dilakukan dengan memberi suatu perlakuan pada subjek penelitian dari dua kelas sebagai replikasi kemudian diobservasi.

Populasi pada penelitian ini adalah seluruh siswa kelas X IPA. 
Sampel diambil secara acak dengan teknik cluster random sampling, sehingga diperoleh 2 (dua) kelas penelitian sebagai sampel, yaitu kelas X IPA 3 sebagai kelas eksperimen dan kelas X IPA 6 sebagai kelas kontrol.

Pada penelitian ini perangkat pembelajaran yang digunakan antara lain silabus, Rencana Pelaksanaan Pembelajaran (RPP), dan Lembar Kerja Peserta Didik (LKPD). Instrumen yang digunakan pada penelitian ini antara lain soal pretes dan postes yang berupa 11 soal essay model mental, lembar observasi keterlaksanaan pembelajaran isusosiosaintifik, dan lembar aktivitas siswa.

Pada penelitian ini dilakukan uji validitas dan reliabilitas untuk mengetahui apakah intrumen yang digunakan layak atau tidak untuk mengumpulkan data. Uji validitas untuk 11 soal uraian model mental digunakan aplikasi SPSS 23.0.Soal dikatakan valid jika $r$ hitung $\geq r_{\text {tabel }}$ dengan taraf signifikan 5\%. Uji reliabilitas dilakukan menggunakan rumus Alpha Cronbach yang kemudian diinterpretasikan dengan menggunakan derajat reliabilitas alat evaluasi menurut Guilford.

Analisis deskriptif terhadap model mental siswa dilakukan dengan menganalisis jawaban-jawaban siswa pada setiap soal tes model mental. Jawaban tersebut dikelompokkan ke dalam beberapa tipe sesuai dengan kemiripan jawaban siswa. Tipe-tipe jawaban siswa diurutkan sesuai dengan jawaban siswa dimulai dari tidak ada upaya (tidak memberikan jawaban) sampai ke jawaban yang paling tepat. Banyaknya siswa pada setiap tipe dinyatakan dalam bentuk persentase dan kriteria interval yang didapatkan dari perhitungan panjang kelas interval (Sudjana, 2005).
Skor model mental tersebut kemudian diubah ke skala 100 dengan rumus:

$$
\mathrm{S}_{100}=(S / T) \times 100
$$

Dimana $\mathrm{S}_{100}$ adalah skor model mental pada skala 100; S adalah skor yang diperoleh siswa; $\mathrm{T}$ adalah skor total.

Pengaruh pembelajaran isu sosiosaintifik dalam penelitian ini ditentukan berdasarkan ketercapaian pembelajaran dalam meningkatkan kemampuan model mental siswa yang diukur melalui skor n-Gain, yaitu selisih antara nilai postes dan nilai pretes dengan rumus dari Hake (2002) dengan kriteria rendah jika nGain $\leq 0,3$; kriteria sedang jika $0,3<n$ Gain $\leq 0,7$; dan kriteria tinggi jika $n$ Gain > 0,7 (Hake, 2002). Aktivitas siswa selama pembelajaran berlangsung diukur dengan menggunakan lembar observasi aktivitas siswa oleh observer.

Analisis data keterlaksanaan pembelajaran diukur melalui penilaian terhadap keterlaksanaan Rencana Pelaksanaan Pembelajaran (RPP) yang memuat unsur-unsur pembelajaran yang meliputi tahapan tahapan dalam sebuah pembelajaran. Analisis data keterlaksanaan RPP dilakukan dengan langkah antara lain menghitung jumlah skor yang diberikan oleh observer untuk setiap aspek pengamatan yang terdapat pada lembar observasi keterlaksanaan pembelajaran, kemudian dihitung persentase ketercapaiannya, setelah itu menghitung rata-rata persentase ketercapaian untuk setiap aspek pengamatan dari dua orang observer yaitu guru mitra dan rekan sejawat.

$$
\text { Menafsirkan data dengan }
$$
tafsiran harga / nilai persentase ketercapaian rancangan pelaksanaan pembelajaran (RPP) sebagaimana 
pada tabel tafsiran berikut ini (Arikunto, 2006):

\begin{tabular}{ll}
$\begin{array}{r}\text { Tabel1.Tafsiran untuk Ketercapaian } \\
\text { Pelaksanaan Pembelajaran }\end{array}$ \\
\hline Persentase & $\begin{array}{l}\text { Kategori } \\
\text { Tanggapan }\end{array}$ \\
\hline $80,1 \%-100 \%$ & Sangat Tinggi \\
$60,1 \%-80 \%$ & Tinggi \\
$40,1 \%-60 \%$ & Sedang \\
$20,1 \%-40 \%$ & Rendah \\
$0,0 \%-20 \%$ & Sangat Rendah \\
\hline
\end{tabular}

Setelah itu dilakukan uji normalitas dan homogenitas terhadap nilai pretes, postes dan $n$-Gain masing - masing kelas dan juga dilakukan uji perbedaan dua rata-rata menggunakan SPSS 23.0 dengan melihat nilai signifikansinya. Uji normalitas dimaksudkan untuk meyakinkan bahwa sampel benarbenar berasal dari populasi yang berdistribusi normal sedangkan uji homogenitas untuk meyakinkan bahwa sampel memiliki varians yang homogen (Sudjana, 2005). Setelah itu, dilakukan uji perbedaan dua ratarata (uji-t) untuk mengetahui apakah suatu perlakuan berpengaruh atau tidak terhadap sampel penelitian. Uji$\mathrm{t}$ yang digunakan yaitu uji independent sample t-test dengan menggunakan nilai $n$-Gain dari kedua kelas. Kriteria ujinya adalah terima $\mathrm{H}_{0}$ jika nilai sig (1-tailed) $<0,05$ yang berarti bahwa rata-rata nilai $n$-Gain model mental siswa kelas eksperimen lebih tinggi daripada rata-rata $n$-Gain model mental siswa kelas kontrol, tolak $\mathrm{H}_{0}$ jika sebaliknya.

Setelah itu dilakukan uji ukuran pengaruh (effect size) untuk mengetahui seberapa besar pengaruh perlakuan terhadap sampel penelitian. Sebelum menghitung effect size, terlebih dahulu dicari nilai t yang diperoleh dari uji independent sample test dengan menggunakan nilai pretes dan postes pada masingmasing kelas. Rumus effect size:

$$
\mu^{2}=\frac{t^{2}}{t^{2}+d f}
$$

dimana $\mu$ adalah effect size; $t$ adalah $t$ hitung dari uji- $t$; $d f$ adalah derajat kebebasan (Abujahjouh, 2014).

Tabel 2. Kriteria Effect Size Menurut Dyncer (2015)

\begin{tabular}{ll}
\hline Effect size $(\mu)$ & Kriteria \\
\hline$\mu \leq 0,15$ & Sangat kecil \\
$0,15<\mu \leq 0,40$ & Kecil \\
$0,40<\mu \leq 0,75$ & Sedang \\
$0,75<\mu \leq 1,10$ & Besar \\
$\mu>1,10$ & Sangat besar \\
\hline
\end{tabular}

\section{HASIL DAN PEMBAHASAN}

\section{Validitas dan Reliabilitas}

Hasil pengujian validitas untuk 11 soal uraian pretes postes model mental disajikan pada Tabel 3.

Tabel 3.Validitas Soal Uraian Pretes Dan Postes Model Mental

\begin{tabular}{cccc}
\hline $\begin{array}{c}\text { Butir } \\
\text { Soal }\end{array}$ & $\begin{array}{c}\text { Koefisien } \\
\text { Korelasi }\end{array}$ & $\mathrm{r}_{\text {tabel }}$ & $\begin{array}{c}\text { Kete- } \\
\text { rangan }\end{array}$ \\
\hline $1 \mathrm{a}$ & 0,984 & 0,444 & Valid \\
$1 \mathrm{~b}$ & 0,980 & 0,444 & Valid \\
$\mathrm{2a}$ & 0,976 & 0,444 & Valid \\
$2 \mathrm{~b}$ & 0,654 & 0,444 & Valid \\
$2 \mathrm{c}$ & 0,818 & 0,444 & Valid \\
3 & 0,838 & 0,444 & Valid \\
$4 \mathrm{a}$ & 0,918 & 0,444 & Valid \\
$4 \mathrm{~b}$ & 0,926 & 0,444 & Valid \\
$5 \mathrm{a}$ & 0,592 & 0,444 & Valid \\
$5 \mathrm{~b}$ & 0,984 & 0,444 & Valid \\
$5 \mathrm{c}$ & 0,801 & 0,444 & Valid \\
\hline
\end{tabular}

Berdasarkan Tabel 3 tersebut, dapat diketahui bahwa $r_{\text {hitung }}$ (koefisien korelasi) lebih besar dari $r_{\text {tabel. }}$ Hal ini menunjukkan bahwa 
instrumen tes model mental pada materi larutan elektrolit dan nonelektrolit dinyatakan valid dan dapat digunakan dalam penelitian. Hasil pengujian reliabilitas soal model mental diperoleh Alpha Cronbach's sebesar 0,785 yang lebih besar dari nilai $r_{\text {tabel, sehingga instrumen tes }}$ model mental juga dinyatakan reliabel dan dapat digunakan dalam penelitian untuk mengukur model mental siswa.

\section{Analisis Data Keterlaksanaan Pembelajaran Berbasis Isu Sosiosaintifik \\ Data hasil keterlaksanaan pembelajaran isu sosiosaintifik disajikan pada Tabel 4 berikut.}

Tabel 4. Persentase Keterlaksanaan

\begin{tabular}{|c|c|c|}
\hline \multicolumn{3}{|c|}{ Pembelajaran } \\
\hline $\begin{array}{l}\text { Perte- } \\
\text { muan }\end{array}$ & Aspek Pengamatan & $\begin{array}{c}\text { Persentase } \\
\text { Keterlaksana } \\
\text {-an }(\%)\end{array}$ \\
\hline \multirow{2}{*}{1} & Kegiatan pendahuluan & $71,875 \%$ \\
\hline & Scientific background & $77,7 \%$ \\
\hline \multirow{6}{*}{2} & $\begin{array}{l}\text { Evaluation of } \\
\text { Information }\end{array}$ & $84,375 \%$ \\
\hline & $\begin{array}{l}\text { Local. National, and } \\
\text { Global Dimension }\end{array}$ & $81,25 \%$ \\
\hline & Decision Making & $87,5 \%$ \\
\hline & Penutup & $81,23 \%$ \\
\hline & PengelolaanWaktu & $84,375 \%$ \\
\hline & Rata-rata & $81,186 \%$ \\
\hline \multirow{11}{*}{3} & Kegiatan pendahuluan & $75 \%$ \\
\hline & Scientific background & $81,25 \%$ \\
\hline & Evaluation of & $90,625 \%$ \\
\hline & Local. National and & $87.5 \%$ \\
\hline & Global Dimension & \\
\hline & Decision Making & $93,75 \%$ \\
\hline & Penutup & $93,75 \%$ \\
\hline & PengelolaanWaktu & $90,625 \%$ \\
\hline & Rata-rata & $87,5 \%$ \\
\hline & Rata-Rata & $84,343 \%$ \\
\hline & Kategori & $\begin{array}{c}\text { Sangat } \\
\text { tinggi }\end{array}$ \\
\hline
\end{tabular}

Berdasarkan Tabel 4 diketahui bahwa persentase keterlaksanaan pembelajaran pada kelas eksperimen secara keseluruhan mengalami peningkatan pada setiap pertemuan dan dikategorikan dalam kriteria 'sangat tinggi', sehingga dapat disimpulkan bahwa keterlaksanaan pembelajaran pada kelas eksperimen terlaksana dengan sangat baik. Peningkatan model mental siswa dipengaruhi dari keterlaksanaan pembelajaran yang terlaksana dengan sangat baik Hal ini sesuai dengan penelitian Harjali (2017) yang menyatakan bahwa interaksi guru dan siswa maupun interaksi antar siswa sangat dipengaruhi oleh segi-segi afektif atau emosional siswa, seperti rasa kenyamanan dan tanggung jawab, keindahan, kondisi pembelajaran yang kondusif, tidak ada tekanan dan tidak ada usaha yang tidak dihargai dalam mengikuti kegiatan pembelajaran. Kondisi kelas yang kondusif secara langsung akan berpengaruh terhadap hasil belajar siswa.
Aktivitas Siswa
Data hasil aktivitas siswa disajikan pada Tabel 5 yang menunjukkan bahwa aktivitas siswa pada pertemuan pertama dan kedua persentase aktivitas siswa tergolong pada kriteria 'tinggi' sedangkan pada pertemuan ketiga persentase aktivitas siswa tergolong pada kriteria 'sangat tinggi'. Artinya siswa telah terlibat secara aktif dalam kegiatan pembelajaran sehingga memudahkan guru untuk mencapai tujuan pembelajaran. Hal ini menunjukkan bahwa persentase aktivitas siswa selama proses pembelajaran mengalami peningkatan pada setiap pertemuannya.
Pembelajaran menggunakan isu sosiosaintifik memiliki tahapan- tahapan yang memungkinkan siswa untuk aktif dalam menerapkan pengetahuan konsep dan proses 
ilmiah yang dipahami untuk mengambil keputusan terhadap isu yang terjadi di masyarakat berdasarkan bukti dalam kehidupan sehari-hari. Hal ini didukung oleh Bruner (2007), belajar penemuan dapat meningkatkan penalaran dan kemampuan berpikir secara bebas dan melatih keterampilan kognitif untuk menemukan dan memecahkan masalah.

Tabel 5. Hasil Pengamatan Aktivitas

\begin{tabular}{|c|c|c|c|c|c|}
\hline \multirow[b]{2}{*}{ No } & \multirow[b]{2}{*}{$\begin{array}{l}\text { Aspek yang } \\
\text { diamati }\end{array}$} & \multicolumn{4}{|c|}{$\begin{array}{c}\text { Persentase Aktivitas } \\
\text { Siswa (\%) }\end{array}$} \\
\hline & & $\begin{array}{c}\text { Perte- } \\
\text { muan } \\
1\end{array}$ & $\begin{array}{c}\text { Perte- } \\
\text { muan } \\
2\end{array}$ & $\begin{array}{c}\text { Perte } \\
\text { muan } \\
\mathbf{3} \\
\end{array}$ & $\begin{array}{c}\text { Rata- } \\
\text { rata }\end{array}$ \\
\hline 1 & $\begin{array}{l}\text { Memperhatikan dan } \\
\text { mendengarkan } \\
\text { penjelasan } \\
\text { guru/teman }\end{array}$ & $\begin{array}{l}75 \\
00\end{array}$ & $\begin{array}{c}80,0 \\
0\end{array}$ & $\begin{array}{l}85 \\
00\end{array}$ & $\begin{array}{l}80,0 \\
0\end{array}$ \\
\hline 2 & $\begin{array}{l}\text { Ulet dalam mencari } \\
\text { sumber pengetahuan } \\
\text { mengenai materi } \\
\text { larutan elektrolit dan } \\
\text { non-elektrolit }\end{array}$ & $\begin{array}{l}75 \\
00\end{array}$ & $\begin{array}{c}80,0 \\
0\end{array}$ & $\begin{array}{l}85 \\
00\end{array}$ & $\begin{array}{c}80,0 \\
0\end{array}$ \\
\hline 3 & $\begin{array}{l}\text { Banyak bertanya } \\
\text { dalam mengikuti } \\
\text { kegiatan pembelajar- } \\
\text { an }\end{array}$ & $\begin{array}{l}75 \\
00\end{array}$ & $\begin{array}{c}80,0 \\
0\end{array}$ & $\begin{array}{l}85 \\
00\end{array}$ & $\begin{array}{c}80,0 \\
0\end{array}$ \\
\hline 4 & $\begin{array}{l}\text { Melibatkan diri } \\
\text { dalam mengerjakan } \\
\text { LKPD/berdiskusi } \\
\text { dengan kelompok }\end{array}$ & $\begin{array}{l}70 \\
00\end{array}$ & $\begin{array}{c}80,0 \\
0\end{array}$ & $\begin{array}{l}85 \\
00\end{array}$ & $\begin{array}{c}80,0 \\
0\end{array}$ \\
\hline 5 & $\begin{array}{l}\text { Terlibat aktif dalam } \\
\text { melakukan percobaan }\end{array}$ & $\begin{array}{c}80 \\
00\end{array}$ & - & - & $\begin{array}{c}80,0 \\
0\end{array}$ \\
\hline 6 & $\begin{array}{l}\text { Mempresentasikan } \\
\text { dan mengemukakan } \\
\text { gagasan dari hasil } \\
\text { diskusi }\end{array}$ & $\begin{array}{l}75 \\
00\end{array}$ & $\begin{array}{l}80,0 \\
0\end{array}$ & $\begin{array}{l}85 \\
00\end{array}$ & $\begin{array}{c}80,0 \\
0\end{array}$ \\
\hline 7 & $\begin{array}{l}\text { Berkomentar/me- } \\
\text { nanggapi presentasi } \\
\text { kelompok lain }\end{array}$ & $\begin{array}{l}70 \\
00\end{array}$ & $\begin{array}{c}75,0 \\
0\end{array}$ & $\begin{array}{l}80 \\
00\end{array}$ & $\begin{array}{c}75,0 \\
0\end{array}$ \\
\hline 8 & $\begin{array}{l}\text { Melibatkan diri } \\
\text { dalam pengambilan } \\
\text { keputusan terkait } \\
\text { dengan isu yang } \\
\text { dibahas }\end{array}$ & $\begin{array}{l}75 \\
00\end{array}$ & $\begin{array}{c}80,0 \\
0\end{array}$ & $\begin{array}{l}85 \\
00\end{array}$ & $\begin{array}{c}80,0 \\
0\end{array}$ \\
\hline & $\begin{array}{l}\text { ata-rata persentase } \\
\text { xtivitas siswa yang } \\
\text { levan }\end{array}$ & $\begin{array}{l}74, \\
37\end{array}$ & 69,3 & $\begin{array}{l}75 \\
75\end{array}$ & $\begin{array}{c}79,3 \\
1\end{array}$ \\
\hline & riteria & nggi & Ting & $\begin{array}{l}\text { Sangat } \\
\text { tinggi }\end{array}$ & Tinggi \\
\hline
\end{tabular}

\section{Analisis Data Kemampuan Model Mental}

Pada kelas eksperimen, model mental siswa secara keseluruhan setelah pelaksanaan pembelajaran dengan menggunakan isu sosiosaintifik tergolong sangat baik. Hal ini ditunjukkan dengan model mental siswa setelah pelaksanaan pembelajaran, sebanyak 22 orang dengan persentase $62,86 \%$ berada pada kategori 'baik sekali', sebanyak 12 orang dengan persentase $34,29 \%$ pada kategori 'baik' dan 1 orang dengan persentase $2,86 \%$ pada kategori 'sedang'. Persentase kriteria model mental siswa sebelum dan setelah pembelajaran ditunjukkan pada gambar 1 sebagai berikut.

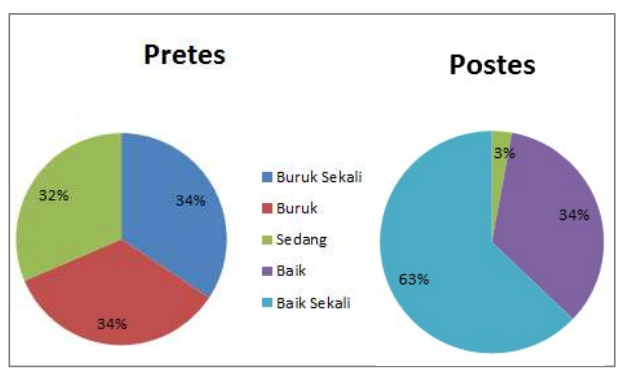

Gambar 1. Persentase Kriteria Model Mental Siswa Sebelum dan Setelah Pembelajaran

Berdasarkan Gambar 1 menunjukkan bahwa kemampuan model mental siswa pada sebelum pembelajaran tergolong pada kriteria 'buruk sekali' dan 'buruk'. Artinya pada saat itu model mental siswa belum terbentuk dan sebagian baru mulai terbentuk. Akan tetapi, terdapat juga siswa yang berada pada kriteria 'sedang'. Hal ini dikarenakan siswa sebelumnya telah membaca materi yang akan dipelajari, sehingga siswa tersebut memiliki kriteria 'sedang'.

Setelah pembelajaran, secara keseluruhan kemampuan model mental siswa tergolong pada kriteria 'sedang' dan 'baik'. Selain itu juga terdapat siswa yang memiliki model mental dengan kriteria 'baik sekali'. Artinya kemampuan model mental siswa mengalami peningkatan, 
dimana kemampuan model mental siswa yang terbentuk sudah mendekati kebenaran keilmuan. Terbentuknya kemampuan model mental siswa menunjukkan adanya peningkatan kemampuan siswa dalam memahami representasi makroskopik, submikroskopik, dan simbolik, serta mampu melakukan interpretasi dan transformasi di antara ketiga level fenomena kimia. Hal ini relevan dengan penelitian Mawarni (2015) yang menyatakan bahwa pembelajaran inkuiri terbimbing berpengaruh dalam meningkatkan model mental dan penguasaan konsep siswa pada materi larutan elektrolit dan non-elektrolit.

Hasil analisis data model mental sebelum dan sesudah dilakukan perlakuan yaitu berupa rata-rata nilai pretes dan postes, ditunjukkan pada Gambar 2 sebagai berikut.

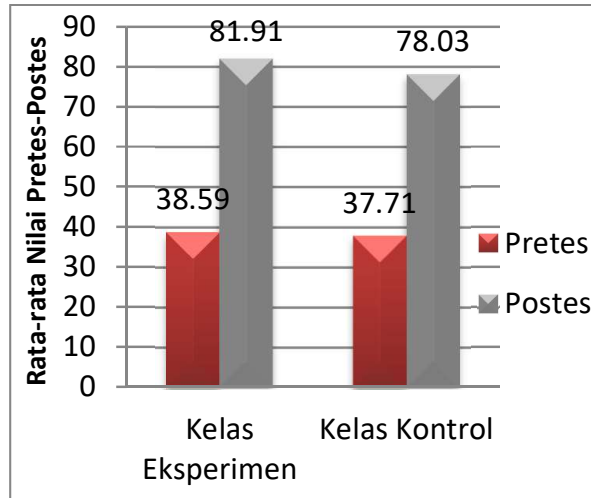

Gambar 2. Diagram Rata-Rata Nilai PretesPostes Kemampuan Model Mental

Berdasarkan Gambar 2, dapat diketahui bahwa rata-rata nilai pretes dan postes model mental siswa pada kelas eksperimen lebih tinggi dibandingan kelas kontrol. Hal ini dikarenakan pada kelas eksperimen dilakukan pembelajaran dengan perlakuan yang berbeda dengan kelas kontrol.

Peningkatan model mental siswa dapat terlihat dari $n$-Gain. Ratarata n-Gain kelas kontrol dan eksperimen disajikan pada Gambar 3 sebagai berikut.

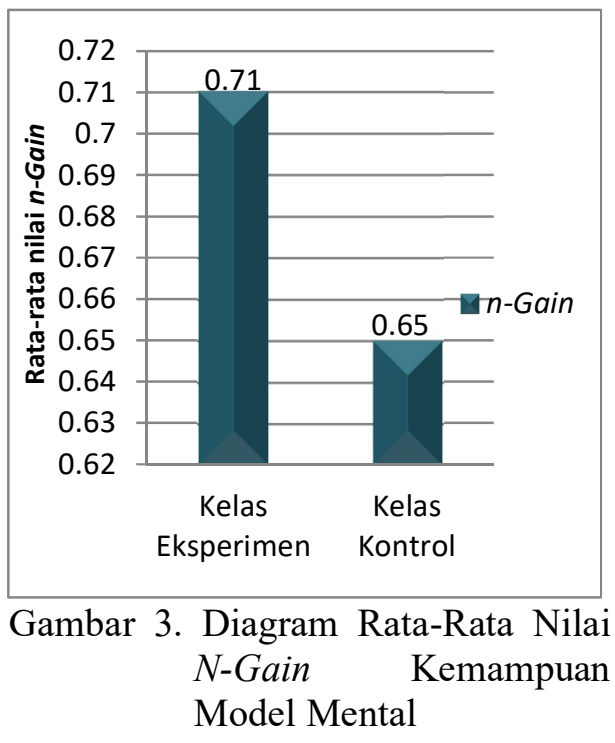

Berdasarkan Gambar 3, dapat diketahui bahwa rata-rata n-Gain pada kelas eksperimen lebih tinggi dibandingkan dengan kelas kontrol. Kriteria n-Gain pada kelas eksperimen yaitu 'tinggi' sedangkan pada kelas kontrol yaitu 'sedang'. Hal ini menunjukkan bahwa peningkatan model mental siswa kelas eksperimen lebih baik dibandingkan kelas kontrol. Dari hasil tersebut juga dapat dinyatakan bahwa penggunaan isu sosiosaintifik berpengaruh untuk meningkatkan kemampuan model mental siswa pada materi larutan elektrolit dan nonelektrolit. Pembelajaran dengan isu sosiosaintifik menuntut siswa untuk menumbuhkan kemampuan berpikir kritis serta menumbuhkan kemampuan untuk menerapkan pengetahuan konsep dan proses ilmiah yang dipahami untuk 
mengambil keputusan terhadap isu yang terjadi di masyarakat.

Pembelajaran menggunakan isu sosiosaintifik dapat meningkatkan kemampuan model mental siswa dikarenakan dalam pembelajarannya terdapat tahapan-tahapan yang melibatkan siswa secara aktif, sehingga pengetahuan yang diperoleh akan bertahan lama. Dengan adanya keterlibatan siswa dalam proses pembelajaran dapat mempengaruhi hasil belajar. Hal ini sesuai dengan penelitian Maisaroh (2017) yang menyatakan bahwa pembelajaran discovery learning mampu meningkatkan model mental dan penguasaan konsep siswa.

Setelah memperoleh hasil pretes, postes dan $n$-Gain, selanjutnya dilakukan uji normalitas dan homogenitas. Hasil uji normalitas nilai pretes, postes, dan $n$-Gain model mental siswa kelas kontrol dan eksperimen disajikan dalam Tabel 6 berikut ini.

Tabel 6. Hasil Uji Normalitas Model

\begin{tabular}{cccc}
\multicolumn{4}{c}{ Mental Siswa } \\
\hline \multirow{2}{*}{ Kelas } & $\begin{array}{c}\text { Aspek } \\
\text { yang } \\
\text { diamati }\end{array}$ & $\begin{array}{c}\text { Nilai } \\
\text { sig. } \\
\text { Model } \\
\text { Mental }\end{array}$ & $\begin{array}{c}\text { Kete- } \\
\text { rangan }\end{array}$ \\
\hline \multirow{3}{*}{ Eksperimen } & Pretes & 0,200 & Normal \\
& Postes & 0,183 & Normal \\
& $n$-Gain & 0,200 & Normal \\
\hline \multirow{3}{*}{ Kontrol } & Pretes & 0,200 & Normal \\
& Postes & 0,200 & Normal \\
& $n$-Gain & 0,154 & Normal \\
\hline
\end{tabular}

Berdasarkan Tabel 6 , hasil uji normalitas yang telah dilakukan terhadap perolehan nilai pretes, postes, dan $n$-Gain model mental siswa kelas eksperimen dan kelas kontrol dapat diketahui bahwa untuk kedua kelas nilai signifikansi $>0,05$ sehingga keputusan uji terima $\mathrm{H}_{0}$ dan tolak $\mathrm{H}_{1}$ yang berarti data penelitian yang diperoleh berdistribusi normal. Hasil uji homogenitas model mental siswa pada kelas eksperimen dan kelas kontrol dapat dilihat pada Tabel 7 berikut.

\begin{tabular}{ccc} 
Tabel & $\begin{array}{c}\text { 7.Hasil Uji } \\
\text { Model Mental Siswa }\end{array}$ & Homogenitas \\
\hline Aspek & Nilai sig. & Keterangan \\
\hline Pretes & 0,210 & Homogen \\
Postes & 0,486 & Homogen \\
$n$-Gain & 0,910 & Homogen \\
\hline
\end{tabular}

Berdasarkan Tabel 7, hasil uji homogenitas terhadap perolehan nilai pretes, postes dan n-Gain model mental siswa diperoleh nilai signifikansi $>0,05$ sehingga keputusan uji terima $\mathrm{H}_{0}$ dan tolak $\mathrm{H}_{1}$ yang berarti data penelitian yang diperoleh berasal dari varians yang homogen.

Berdasarkan hasil kedua uji di atas diperoleh hasil yang menunjukkan bahwa kedua sampel berdistribusi normal dan memiliki varians yang homogen, maka dilakukan uji hipotesis parametrik dengan menggunakan uji perbedaan dua rata-rata yaitu uji Independent Sample T-Test. Uji ini dilakukan untuk mengetahui apakah terdapat pengaruh atau tidak dari pembelajaran yang telah diberikan pada kedua kelas. Setelah dilakukan pengujian diperoleh hasil uji perbedaan dua rata-rata pada kelas eksperimen dan kelas kontrol yang disajikan pada Tabel 8 berikut.

Tabel 8. Hasil Uji Perbedaan Dua Rata-Rata Pretes-Postes

\begin{tabular}{cccc}
\hline Kelas & \multicolumn{3}{c}{ Kemampuan Model Mental } \\
\cline { 2 - 4 } Penelitian & Df & Nilai t & $\begin{array}{c}\text { Nilai sig. } \\
\text { (2-tailed) }\end{array}$ \\
\hline Eksperimen & 68 & $-16,490$ & 0,000 \\
Kontrol & 70 & $-13,234$ & 0,000 \\
\hline
\end{tabular}


Berdasarkan Tabel 8 di atas keputusan uji terima $\mathrm{H}_{1}$ dan tolak $\mathrm{H}_{0}$, maka pembelajaran menggunakan isu sosiosaintifik yang telah dilakukan dikatakan efektif dalam meningkatkan kemampuan model mental siswa pada materi larutan elektrolit dan nonelektrolit. Selain itu diketahui bahwa nilai $t$ dari uji perbedaan dua rata-rata pretes-postes yang diperoleh pada kelas eksperimen lebih kecil dibandingkan dengan kelas kontrol. Hasil uji perbedaan dua rata-rata iniselanjutnya digunakan untuk menghitung effect size yang disajikan pada Tabel 9 berikut.

\begin{tabular}{ccc}
\multicolumn{2}{l}{ Tabel 9.Hasil Perhitungan Effect Size } \\
\hline Kelas & \multicolumn{2}{c}{ Kemampuan Model } \\
Penelitian & \multicolumn{2}{c}{ Mental } \\
& Effect Size & Kriteria \\
\hline Eksperimen & 0,894 & Besar \\
Kontrol & 0,845 & Besar \\
\hline
\end{tabular}

Berdasarkan Tabel 9, nilai effect size pada kelas eksperimen lebih besar daripada kelas kontrol. Pada kelas eksperimen mempunyai nilai effect size sebesar 0.894 sedangkan pada kelas kontrol mempunyai nilai effect size sebesar 0.845. Sesuai dengan kriteria menurut Dincer (2015) nilai tersebut terletak pada kisaran $0,75<\mu \leq 1,10$ dengan kriteria efek 'besar'.

Hal tersebut menunjukkan bahwa pada kelas eksperimen $89 \%$ peningkatan model mental siswa dengan $n$-Gain tinggi dipengaruhi oleh pembelajaran berbasis isu sosiosaintifik, sedangkan pada kelas kontrol $84 \%$ peningkatan kemampuan model mental siswa dengan $n$-Gain sedang dipengaruhi oleh pembelajaran tanpa menggunakan isu sosiosaintifik. Dapat disimpulkan bahwa penggunaan isu sosiosaintifik dalam pembelajaran mampu meningkatkan kemampuan model mental siswa lebih tinggi dibandingkan dengan pembelajaran tanpa menggunakan isu sosiosaintifik. Hal ini sesuai dengan penelitian Putriana (2018) yang menyatakan bahwa model pembelajaran menggunakan isu sosiosaintifik berpengaruh besar untuk meningkatkan literasi kimia dan metakognisi siswa pada materi larutan elektrolit dan non-elektrolit.

\section{SIMPULAN}

Pembelajaran menggunakan isu sosiosaintifik memiliki efek yang besar dalam meningkatkan kemampuan model mental siswa pada materi larutan elektrolit dan nonelektrolit. Selain itu juga dipengaruhi oleh data pendukung keterlaksanaan pembelajaran isu sosiosaintifik yang berkategori sangat tinggi.

\section{DAFTAR RUJUKAN}

Abujahjouh, Y. M. 2014. The Effectiveness of Blanded ELearning Forum in Planning for Science Intruction. Journal of Turkish Science Education, 11(4): 3-16.

Arikunto, S. 2006. Dasar-Dasar Evaluasi Pendidikan. Jakarta: Bumi Aksara.

Coll, R. K. 2008. Chemistry Learners' Preferred Mental Models for Chemical Bonding. Journal of Turkish Science Education, 5(1): 22-47.

Davidowitz, B., Gail Chitteleborough, and Eileen Murray. 2010. Student Generated Submicro Diagrams: a Useful Tool for Teaching And Learning Chemical Equations and Stoichiometry. Chemical 
Education Research and Practice, 11(1): 154-164.

Dyncer, S. 2015. Effects of Computer-Assisted Learning on Students' Achievements in Turkey: A Meta-Analysis. Journal of Turkish Science Education, 12(1).

Frankel, J. R., N. E. Wallen, \& Hyun, H. H. 2012. How to Design and Evaluate Research in Education (Eight Edition). New York: McGrow-Hill.

Gutierez, S. B.2015. Integrating Socio-Scientific Issuess to Enhance the Bioethical Decision-Making Skill of High School Students. International Education Studies, 8(1). Doi: 10.5539/ies.v8n1p142.

Harjali, H. 2017. Strategi Guru dalam Membangun Lingkungan Belajar yang Kondusif: Studi Fenomenologi pada KelasKelas Sekolah Menengah Pertama di Ponorogo. Jurnal Pendidikan dan Pembelajaran, 23(1): 010-019.

Halim, N. D. Abd. 2013. Mental Modelin Learning Chemical Bonding : A Preliminary Study Procedia. Social and Behavioral Science, 97(1): 224-228

Hake, R. R. 2002. Relationship of Individual Student Normalized Learning Gains in Mechanics with Gender, High School Physics, and Pretest Scores in Mathematics and Spatial Visualization. Online: http://www.physics.indiana.edu/ นhake. Diakses 22 November 2018

Johnstone, A. H. 2006. Chemical Education Research in Glasgow in Perspective. Journal Chemistry Education Research and Practice, 7(2): 49-63.
Junaina.2013. Pengaruh Pembelajaran Kerangka IFSO terhadap Peningkatkan Model Mental dan Penguasaan Konsep Ikatan Kimia Siswa SMA Negeri 1 Way Lima.(Tesis). Program S2 Teknologi Pendidikan. Program Pascasarjana Universitas Lampung: Tidak Dipublikasikan.

Laliyo, L. A. R. 2011. Model Mental Siswa dalam Memahami Perubahan Wujud Zat. Jurnal Penelitian dan Pendidikan Universitas Negeri Gorontalo, 8(1): 1-12.

Maisaroh, D., Rudibyani, R. B., dan Sofya, M. 2017. Pembelajaran Discovery Learning dalan Meningkatkan Model Mental dan Penguasaan Konsep Siswa. Jurnal Pendidikan dan Pembelajaran Kimia,6(2): 334346.

Mawarni, D., Rudibyani, R. B., dan Efkar, T. 2015. Pembelajaran Inkuiri Terbimbing dalam Meningkatkan Model Mental Siswa Dan Penguasaan Konsep Siswa Pada Materi Larutan Elektrolit Dan Non-elektrolit. Jurnal Pendidikan dan Pembelajaran Kimia, 4(3): 112.

Mazfufah, N.F. 2017. Pengaruh Metode Diskusi Isu-Isu Sosiosaintifik Terhadap Kemampuan Penalaran Ilmiah Peserta Didik. (Skripsi). Jakarta: Universitas Islam Negeri Syarif Hidayatullah.

Putriana, Sunyono, \& Diawati, C. 2018. Pengaruh Penggunaan Isu Sosiosaintifik untuk Meningkatkan Kemampuan Literasi Kimia dan Metakognisi Siswa Pada Materi Larutan Elektrolit dan Non-Elektrolit. 
Jurnal Pendidikan dan Pembelajaran Kimia, 7(2): 112.

Sadler, T. D., and Zeidler, D. L. 2002.

The Morality of Socioscientific Issuess: Construal and Resolution of Genetic Engineering Dilemmas. Science Education 8(8): 4-27. DOI $10.1002 /$ sce. 10101

Sudjana. 2005. Metode Statistika. Bandung: Tarsito.

Sunyono, Wirya, I. W., Suyanto, E., dan Suyadi, G. 2009. Identifikasi Masalah Kesulitan dalam Pembelajaran Kimia SMA Kelas X di Propinsi Lampung. Journal Pendidikan MIPA , 10(2): 9-18.

Sunyono. 2013. Buku Model Pembelajaran Berbasis Multipel Representasi (Model SiMaYang). Bandar Lampung: Aura Press.
Sunyono, Yunita, L., \& Ibrahim, M. 2013. Keterkaitan Model Mental Mahasiswa dengan Penguasaan Konsep Stoikiometri Sebelum dan Sesudah Pembelajaran Dengan Model SiMaYang. Prosiding Seminar nasional PPs, 499-509. Sunyono, Yuanita, L., \& Ibrrahim, M. 2015a. Mental Models of Students on Stoichiometry Concept in Learning by Method Based on Multiple Representation. The Online Journal of New Harizons in Education, 5(2): 30-45.

Zeidler, D.L, Sadler, T.D, Simmons, M.L \& Howes, E.V. 2005. Beyond STS: A ResearchBased Framework for Socioscientific Issuess Education. Science Education 89: $\quad 357-377 . \quad$ DOI $10.1002 /$ sce. 20048 . 